\title{
Drought identification in the eastern Baltic region using NDVI
}

\author{
Egidijus Rimkus ${ }^{1}$, Edvinas Stonevicius ${ }^{1}$, Justinas Kilpys ${ }^{1}$, Viktorija Maciulyte ${ }^{1}$, and Donatas Valiukas ${ }^{2}$ \\ ${ }^{1}$ Department of Hydrology and Climatology, Institute of Geosciences, Vilnius University, Čiurlionio str. 21, \\ Vilnius, 03101, Lithuania \\ ${ }^{2}$ Division of Climatology, Lithuanian Hydrometeorological Service, Rudnios str. 6, Vilnius, 09300, Lithuania
}

Correspondence to: Egidijus Rimkus (egidijus.rimkus@gf.vu.lt)

Received: 10 January 2017 - Discussion started: 18 January 2017

Revised: 31 May 2017 - Accepted: 5 June 2017 - Published: 17 July 2017

\begin{abstract}
Droughts are phenomena that affect large areas. Remote sensing data covering large territories can be used to assess the impact and extent of droughts. Drought effect on vegetation was determined using the normalized difference vegetation index (NDVI) and Vegetation Condition Index (VCI) in the eastern Baltic Sea region located between $53-60^{\circ} \mathrm{N}$ and $20-30^{\circ} \mathrm{E}$. The effect of precipitation deficit on vegetation in arable land and broadleaved and coniferous forest was analysed using the Standardized Precipitation Index (SPI) calculated for 1- to 9-month timescales. Vegetation has strong seasonality in the analysed area. The beginning and the end of the vegetation season depends on the distance from the Baltic Sea, which affects temperature and precipitation patterns. The vegetation season in the southeastern part of the region is 5-6 weeks longer than in the northwestern part. The early spring air temperature, snowmelt water storage in the soil and precipitation have the largest influence on the NDVI values in the first half of the active growing season. Precipitation deficit in the first part of the vegetation season only has a significant impact on the vegetation on arable land. The vegetation in the forests is less sensitive to the moisture deficit. Correlation between VCI and the same month SPI1 is usually negative in the study area. It means that wetter conditions lead to lower VCI values, while the correlation is usually positive between the VCI and the SPI of the previous month. With a longer SPI scale the correlation gradually shifts towards the positive coefficients. The positive correlation between 3- and 6-month SPI and VCI was observed on the arable land and in both types of forests in the second half of vegetation season. The precipitation deficit is only one of the vegetation condition drivers and NDVI cannot be used universally to identify droughts, but it may be applied to better assess the effect of droughts on vegetation in the eastern Baltic Sea region.
\end{abstract}

\section{Introduction}

Vegetation indices derived from remote sensing data are very important for the accurate assessment of plant growing conditions, especially in the case of extreme weather events, such as droughts. Ground-based meteorological and agrometeorological drought indices only allow the evaluation of the risks for agricultural lands, while the satellite information makes it possible to identify damaged vegetation in various land types and to assess the magnitude of damage.

Remote sensing of the vegetation condition is based on the fact that healthy plants have more chlorophyll and therefore absorb more visible (VIS) radiation and reflect more nearinfrared (NIR) radiation (Myneni et al., 1995). Often vegetation conditions are determined by calculating the normalized difference vegetation index (NDVI). Since 1981 this index has been provided on a global scale using the advanced veryhigh-resolution radiometer (AVHRR) instruments on-board NOAA satellites.

The long-term data set is a big advantage, but problems may arise in interpreting the index changes. During more than 30 years of measurements, the land use has been changed in many locations and it is difficult to determine the climatic signal in the NDVI changes. The accuracy of the 
growing conditions evaluation depends on the assessment of environmental and atmospheric conditions as well as peculiarities of the sensor response (Jackson and Huete, 1991). During the period without precipitation, NDVI values can decrease not only due to the deterioration of the plant but also due to the increase in dust in the air and on the surface of the plant, which is usually washed out along with the rain. For this reason, the vegetation index can have lower values than it should (Mirzaei et al., 2011).

It is necessary to emphasize that the vegetation (and hence NDVI values) response to the meteorological conditions in a given year depends on the geographical region and environmental factors such as vegetation type, soil type and land use (Usman et al., 2013). NDVI is a good indicator of vegetation-soil moisture conditions, but seasonality should be taken into account when using this index for drought monitoring (Ji and Peters, 2003). Therefore, in most cases NDVI values are complexly analysed with ground-based meteorological and agrometeorological drought indicators such as the Standardized Precipitation Index (SPI) (Ji and Peters, 2003; Bhuiyan et al., 2006; Quiring and Ganesh, 2010; Gebrehiwot et al., 2011; Gaikwad and Bhosale, 2014; Stagge et al., 2015), Standardized Precipitation Evapotranspiration Index (SPEI) (Stagge et al., 2015), Standardized Water-Level Index (SWI) (Bhuiyan et al., 2006), Palmer drought severity index (PDSI) and Moisture Anomaly Index ( $z$ index) (Quiring and Ganesh, 2010). Most commonly, the spatial and temporal variability in the drought is associated with precipitation deficit; thus, the SPI is often used due to its simplicity (Gebrehiwot et al., 2011).

Previous studies have shown that the NDVI and SPI values are correlated and this relation is the strongest in the middle of the active growing season and the weakest at the beginning and at the end (Ji and Peters, 2003). However, a negative NDVI anomaly cannot be related with low SPI values in all cases (Bhuiyan et al., 2006). The strongest relationship between SPI and NDVI was found in the areas with low soil water-holding capacity (Ji and Peters, 2003). Also, the relationship between these two indices differs in various agricultural areas: a positive correlation between SPI and NDVI was determined in the rain-fed areas, while a negative correlation was determined in the irrigated areas (Ozelkan et al., 2016). The SPI indicates moisture conditions and the vegetation reacts to the lack of precipitations with some delay. For this reason, the strongest link was established between the SPI values in spring and NDVI values in summer, which means that spring watering is critically important for the growth of the most plants (Ozelkan et al., 2016).

NDVI is frequently analysed by calculating Vegetation Condition Index (VCI), which compares the current NDVI to the observed values of this index in previous years (Gebrehiwot et al., 2011; Ozelkan et al., 2016) and has a good correlation with the SPI values (Dutta et al., 2015). In different regions of the world, the relationship between the 3(Gebrehiwot et al., 2011), 6- or 9-month SPI (Quiring and
Ganesh, 2010) and VCI values were established. Some studies showed that the impact of the short-term precipitation fluctuations on VCI values is weak (Quiring and Ganesh, 2010).

The eastern coast of the Baltic Sea is in a transitional area from the maritime to the continental climate, characterized by a strong west-east gradient in the continentality of climate (Jaagus et al., 2010, 2014). The region can be divided into three geographical zones: the western coastal areas, the central agricultural zone with fertile soils, and the eastern region, which contain most lakes, swamps and forest. The spatial pattern of seasonal temperature and precipitation in the Baltic countries depends on two main large-scale factors: latitude and the Baltic Sea (Jaagus et al., 2010, 2014). In the eastern Baltic region droughts are not very common (Loyd-Hughes and Saunders, 2002), but they can cause significant losses for economy and wildlife (BACC, 2008). During the second half of the 20th century the dryness of the region remained similar or even decreased (Bordi et al., 2009; Rimkus et al., 2012, 2013), but recent studies show that in the 21st century, at least in some parts of the study area, the water availability is likely to decrease in summer and autumn (Stonevicius et al., 2017). Dry periods are related to the atmospheric circulation patterns and can affect large areas (Rimkus et al., 2014). In temperate and boreal climates the effect of water shortage on vegetation is not as significant as in arid or semiarid areas, but there is strong evidence of water deficit effect on various types of vegetation in the study area (Kulikauskas and Sprainaitiene, 2005; Vitas and Erlickyte, 2008; Ozolincius et al., 2009; Kalbarczyk, 2010; Bijak, 2011).

The NDVI and VCI have not been used for the drought analysis in the Baltic Sea region yet. In this region, especially in the southern part, the agriculture is strongly developed, and development of new methods for evaluation of drought extension and intensity are very important.

The main objectives of this study are to determine the impact of the droughts on the active plant growing conditions in the eastern part of the Baltic region, to identify other factors that may lead to negative NDVI anomalies or low VCI values during the active growing season, and to find links between SPI and VCI values. Areas of arable land and broadleaved and coniferous forests were analysed separately and differences in precipitation deficit impact on vegetation in different land use types were determined.

\section{Data and methods}

The analysed area covers the eastern part of the Baltic Sea region and is located between $53-60^{\circ} \mathrm{N}$ and $20-30^{\circ} \mathrm{E}$ (Fig. 1). The NDVI was used to analyse the vegetation condition in the land cells of the study area. CORINE (Coordination of Information on the Environment) land cover data were used to identify the response of vegetation in different land use types to precipitation deficit. CORINE land cover data are 


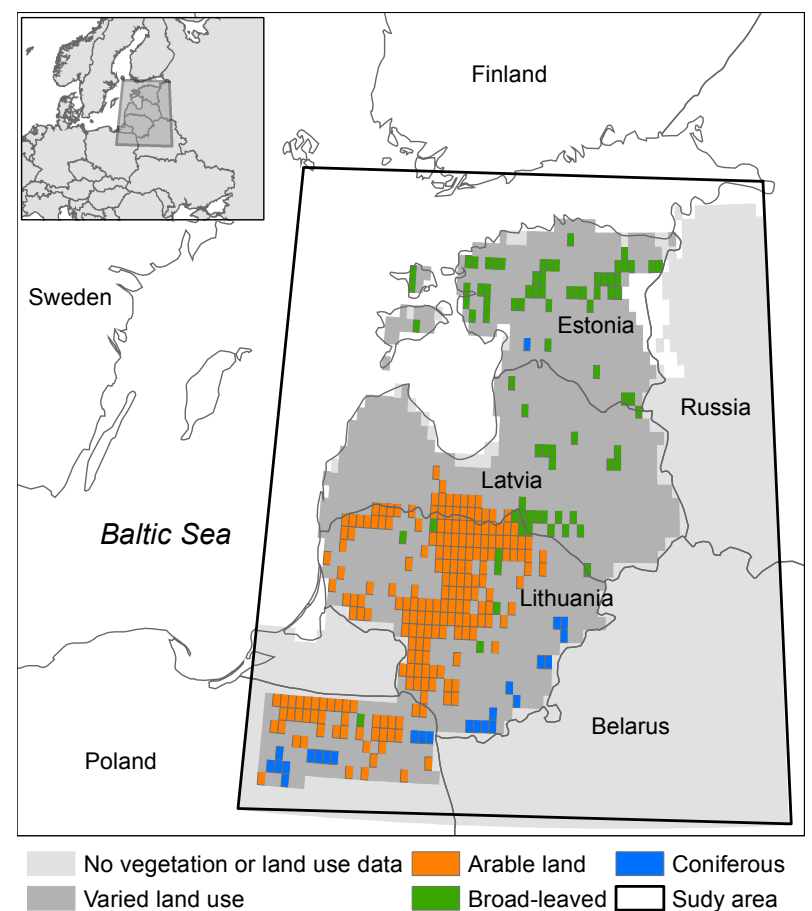

Figure 1. Study area in the eastern part of the Baltic Sea region. The dominant type of land use in $0.144^{\circ} \times 0.144^{\circ}$ cells was estimated according to the CORINE land use data.

available only in part of study area covering Estonia, Latvia, Lithuania and Poland (Fig. 1).

The NDVI data set was obtained from the NOAA STARNESDIS system, which generates global and regional vegetation health data. The NDVI is derived from the radiance observed by the AVHRR on-board polar orbiting satellites: the NOAA-7, NOAA-9, NOAA-11, NOAA-14, NOAA-16, NOAA-18 and NOAA-19. NDVI is calculated as the difference between reflectance in NIR and VIS radiation by following Eq. (1):

$\mathrm{NDVI}=\frac{(\mathrm{NIR}-\mathrm{VIS})}{(\mathrm{NIR}+\mathrm{VIS})}$

The NOAA STAR-NESDIS NDVI product has $16 \mathrm{~km}$ spatial and 7-day composite temporal resolution and covers a period from 1981 to present. In this study, data from 1982 to 2014 were analysed. The NDVI data set is generated using the maximum-value composite (MVC) method (Holben, 1986). This method reduces the influence on NDVI from clouds, spectral properties, resolution and residual atmospheric effects that all act to reduce NDVI (Scheftic et al., 2014). The NOAA STAR-NESDIS system produces no noise NDVI. The NDVI is filtered in order to eliminate the high-frequency noise. It is also adjusted for a non-uniformity of the land surface due to the climate and ecosystem differences using multi-year NDVI and brightness temperature data. The final NDVI product is provided in the geographic grid with equal latitude and longitude intervals $\left(0.144^{\circ} \times 0.144^{\circ}\right)$ (NOAANESDIS, 2013). The data set has several gaps: from week 50 of 1984 to week 8 of 1985, from week 37 of 1994 to week 3 of 1995 , and from weeks 2 to 4 , from weeks 11 to 24 and week 29 of 2004.

The NDVI values range from -1 to +1 . The negative index value can be recorded over the water bodies while values are close to 0 over the land without vegetation. The index value equal to 1 indicates perfect growing conditions (Lillesand and Kiefer, 1994; Belal et al., 2014).

The total number of analysed cells is 2184 . In the coastal areas or near the big lakes, 31 cells were unequally recognized as land or sea cells by different satellites, and in some cases, the information was missing. In such cases, data derived from these particular cells were excluded from further analysis. Also, 99 cells near the sea coast and probably partly covered by the sea, had negative NDVI values during the active growing season and thus were excluded from analysis. In total, $6 \%$ of the initial data set was not used in the study.

The NDVI values are not only influenced by the natural variation in and health of vegetation. In long-term data sets, variability related to the satellite orbital drift, sensor degradation and satellite change is also determined (Kogan, 1997). The initial trend observed in this research was mostly related to the satellite change and this trend was removed by applying a systematic correction for each satellite datum separately.

Active plant vegetation in the eastern Baltic region starts when the daily mean air temperature exceeds $10^{\circ} \mathrm{C}$. In the majority of years this happens in the first half of May. The end of the active growing season usually occurs in the second half of September. It is necessary to mention that there is a difference in growing season of up to several weeks in the study area (due to the latitude and distance from the sea), as well as quite large year-to-year variation in such dates.

Since the drought makes the greatest impact on the plants during the active growing season, data from weeks 18 to 39 of the year (May-September) were analysed. Not only absolute NDVI values were evaluated but also their deviations from the mean. For this reason, VCI (Kogan, 1995) was calculated. VCI compares the current NDVI with measured historical NDVI values. It is defined as the following Eq. (2):

$\mathrm{VCI}=\frac{\mathrm{NDVI}-\mathrm{NDVI}_{\min }}{\mathrm{NDVI}_{\max }-\mathrm{NDVI}_{\min }} \times 100$,

where NDVI is the measured monthly (weekly) value and $\mathrm{NDVI}_{\min }$ and $\mathrm{NDVI}_{\max }$ are the historical minimum and maximum values of the analysed month (week). Lower VCI values indicate a bad vegetation state, while higher values show a good vegetation state. The VCI is expressed as a percentage and varies from 0 to 100. According to Kogan (2002) low values below $<40$ can be described as mild drought, $<30$ as moderate drought, $<20$ as severe drought and $<10$ as extreme drought. 
According to Jain et al. (2010), the VCI is a better indicator of the moisture deficit than NDVI because it allows the separation of the short-term climate signal from the longterm ecological signal. VCI enables the comparison of simultaneously measured NDVI values not only under the different geographic conditions but also in the different vegetation types.

CORINE land cover data were used to identify the dominant land use type in the NDVI cells $\left(0.144^{\circ} \times 0.144^{\circ}\right)$. CORINE data sets with $100 \mathrm{~m}$ resolution were used. The CORINE data sets with reference years 1990 (CLC 1990) and 2012 (CLC 2012) were compared to identify the land use changes during the study period. It was considered that land use in a particular NDVI cell was stable if CORINE land use classes coincided in at least $80 \%$ of the cell area. From the set of cells with stable land use, the cells with different dominant land use types were identified. Diverse land use is common in the analysed region. To reduce the number of CORINE land use classes, the mixed forests and transitional woodland-shrub areas were joined with broadleaved forests and the broadleaved vegetation class was formed. On average, the broadleaved vegetation class consisted of $28 \%$ broadleaved forests, $57 \%$ mixed forests and $15 \%$ transitional woodland-shrub areas. A land use class is considered dominant if it covers at least $50 \%$ of the cell area. Only three types of land use were identified as dominant in more than five cells: arable land (209 cells), broadleaved forest (80) and coniferous forest ( 25 cells) (Fig. 1). These three land use types were used in this study to differentiate the effect of climatic conditions on vegetation.

Four cases with strong NDVI anomalies were investigated. Winter 1987 was one of the coldest winters during the entire study period in the whole eastern Baltic region. Also, it was the only year when the mean March-April temperature averaged over the entire area was negative $\left(-1^{\circ} \mathrm{C}\right)$, and it led to a very late beginning of the vegetation season. In 1990, after one of the warmest winters, a particularly high air temperature in March-April was recorded $\left(5.9^{\circ} \mathrm{C}\right)$, and this led to a very early beginning of the vegetation season. Years 1992 and 2002 were analysed because the largest negative precipitation anomalies in May-September were recorded, 37 and $43 \%$ respectively below the long-term average. During these years the agrometeorological droughts were observed in the substantial part of the analysed area (Valiukas, 2015).

In order to assess the impact of precipitation deficit on vegetation condition, the SPI was used in this study. The SPI calculation for any location is based on a monthly rainfall data series, first applying gamma distribution and then transforming it into a normal distribution (McKee et al., 1993; Edwards and McKee, 1997). Positive SPI values indicate precipitation amounts that are greater than average while negative values indicate lower amounts (Table 1).

High-resolution $\left(0.5^{\circ} \times 0.5^{\circ}\right.$ latitude-longitude $)$ monthly precipitation data from CRU TS (Climate Research Unit Time Series) data set (Harris et al., 2013) have been used
Table 1. Interpretation of SPI values (McKee et al., 1993).

\begin{tabular}{ll}
\hline Value & Interpretation \\
\hline$\geq 2.0$ & Extremely wet \\
$1.99-1.5$ & Very wet \\
0.99 to -0.99 & Near normal \\
-1 to -1.49 & Moderately dry \\
-1.5 to -1.99 & Severely dry \\
$\leq-2.0$ & Extremely dry \\
\hline
\end{tabular}

in this study to calculate SPI values. The initial analysis indicated that the vegetation conditions are not strongly affected by the moisture deficit calculated for timescales above 9 months. The effect of long-term SPI might be weakened by the conditions of the cold season when water supply depends on the precipitation type, snowmelt and soil condition. The 1-, 3-, 6- and 9-month SPI values (SPI1, SPI3, SPI6) were used in this study to investigate the effect of short- and medium-term precipitation deficit.

\section{Results}

\subsection{Spatial and temporal variation in NDVI}

Vegetation has a very strong seasonality in the eastern Baltic region due to the variation in the day length, insolation and air temperature. During the cold season NDVI values in most of the cells are below 0.1 and begin to increase in the second half of March (Fig. 2). The NDVI change from March until May follows a clear spatial pattern. First, the NDVI increases in the southern part of the study area and near the Baltic Sea coast. With time, vegetation index increases towards the northeast. At the end of April NDVI exceeds 0.2 in the entire study area. The largest NDVI values are reached in June and July. A peak of vegetation was usually recorded around 18-24 June. Smaller values (NDVI < 0.50) are more common in the southern part of the domain (Fig. 2). NDVI begins to decline in August. In September NDVI in the majority of the study area drops below 0.40 . From the beginning of October, the NDVI values start to decrease from the northeastern part of the study area, and in the beginning of November NDVI values remain larger than 0.2 only in the several cells located in the southwestern part of the domain (Fig. 2). The length of the period with NDVI higher than 0.2 in the southwestern part of the study area is 5-6 weeks longer than in the northeastern part.

There is a clear difference in the seasonal pattern of NDVI in the different land uses (Fig. 3). NDVI in the cells with dominant arable land cover and broadleaved vegetation is below 0.20 until the middle of April. Later it gradually increases until the first half of June. From the second half of June, NDVI decreases in the cells with both arable land and broadleaved vegetation. The rate of NDVI decrease in the cells with arable land is much sharper than in the cells with 

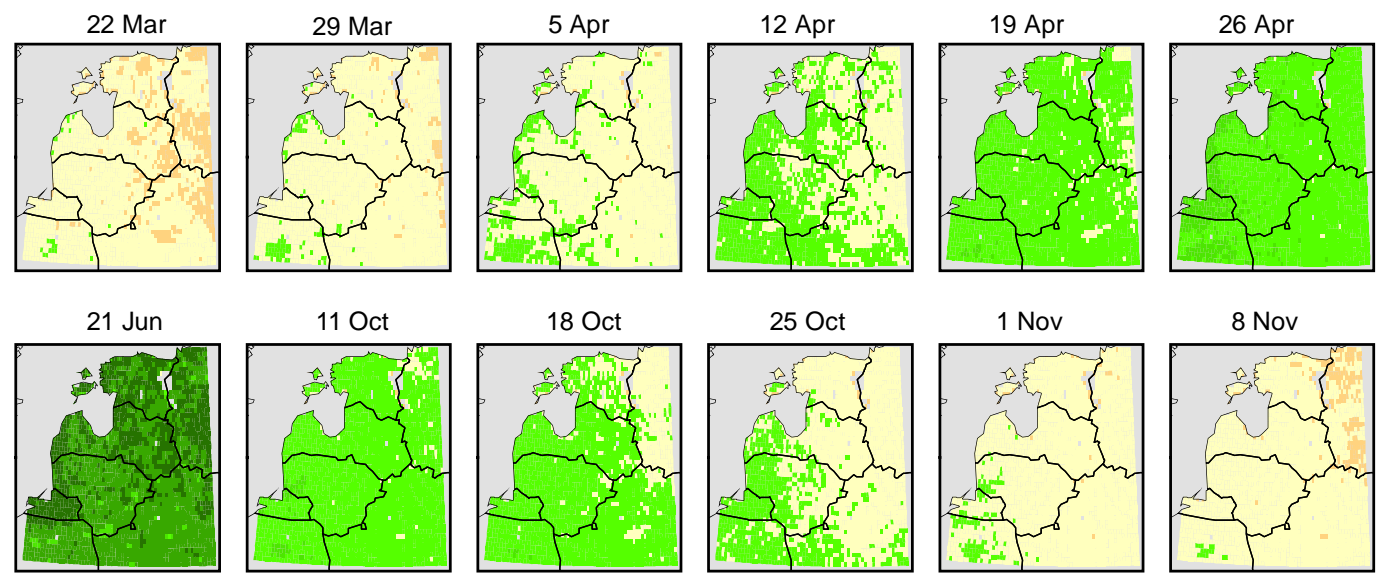

No data

$0.00-0.10$

$0.11-0.20$

$0.21-0.30$

$0.31-0.40$

$0.41-0.50$

$0.51-0.65$

Figure 2. Median of weekly 1982-2014 NDVI in spring (from 22 March to 26 April), autumn (from 11 October to 8 November) and during the vegetation peak (18-24 June) in the eastern part of the Baltic Sea region. Dates are the midpoints of weekly NDVI data.

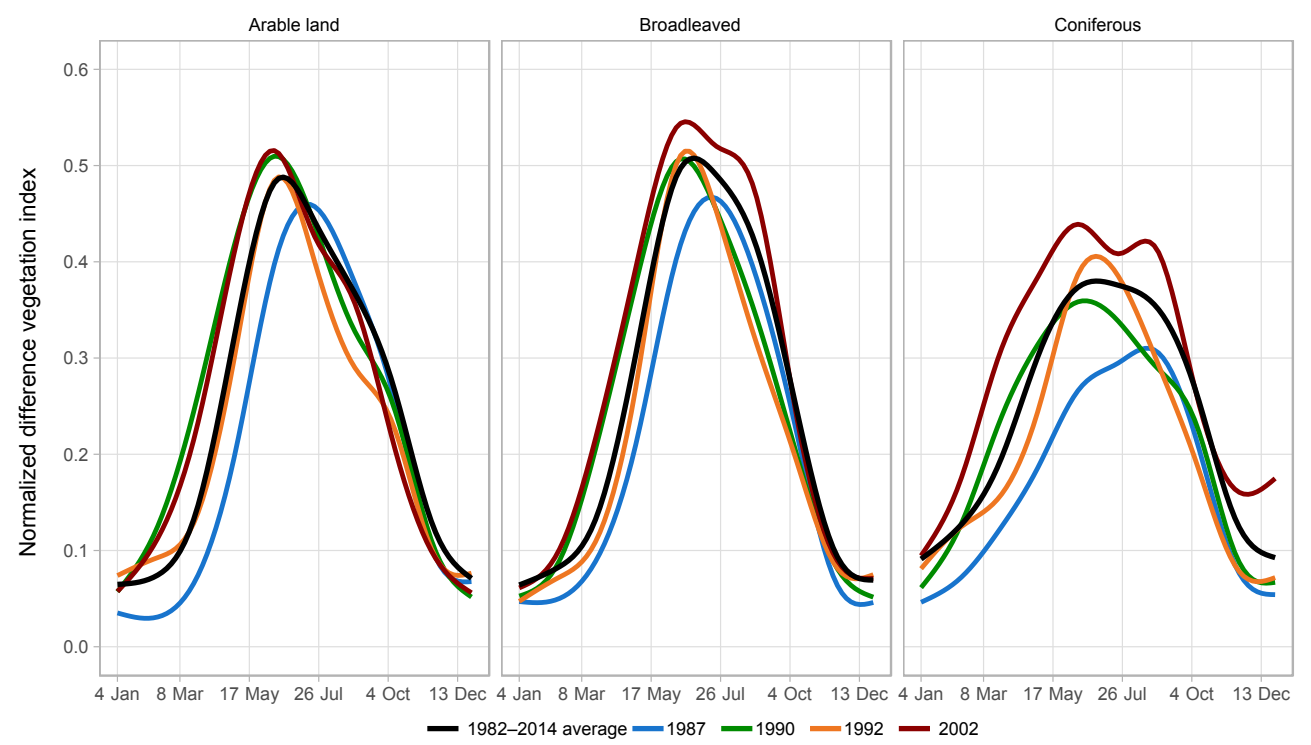

Figure 3. NDVI profile for different land uses of multi-annual average (1982-2014) years with cold (1987), warm (1990), winter and spring seasons, and during the years with a precipitation deficit $(1992,2002)$.

broadleaved vegetation. The difference in the NDVI pattern may be attributed to the difference in vegetation type and land management practices. The annual plants are commonly seeded on the arable land and such vegetation has a faster vegetation cycle. Moreover, the crops in the case study area are harvested in August and September. NDVI has lower seasonality in the cells dominated by coniferous vegetation. In this land cover type the NDVI values remain higher than in other vegetation classes during the cold season and are more stable during the warm season, but on average the highest NDVI values do not exceed 0.4 (Fig. 3).

During a particular year, the seasonal NDVI pattern may considerably differ from the multi-annual average. In 1990 and 2002 spring was warmer than usual and it likely led to the higher NDVI values in the first half of the active growing season in the cells with all land uses (Fig. 3). The 2002 summer was among the driest during the analysed period. Despite this the NDVI remained higher than average on the arable land until the end of July, and in the cells with broadleaved and coniferous vegetation the NDVI remained above the average until the beginning of October. In 1987 winter and spring were colder than usual. This led to the vegetation season starting 2-3 weeks later. In all land use classes, the NDVI was considerably smaller than average. The late start of vegetation in 1987 also led to the late end. However, there is not 

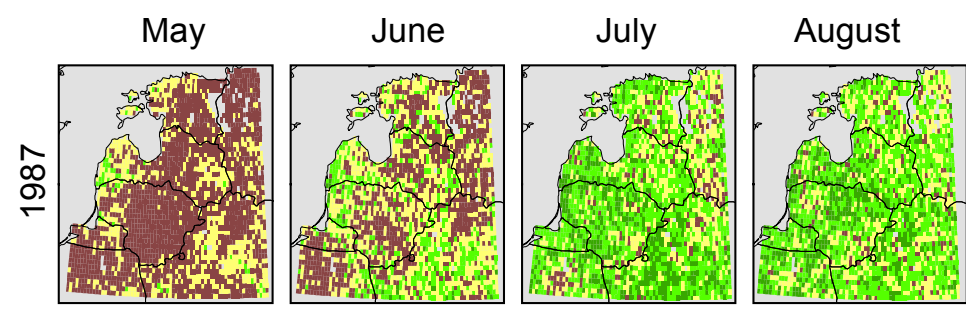

\section{September}
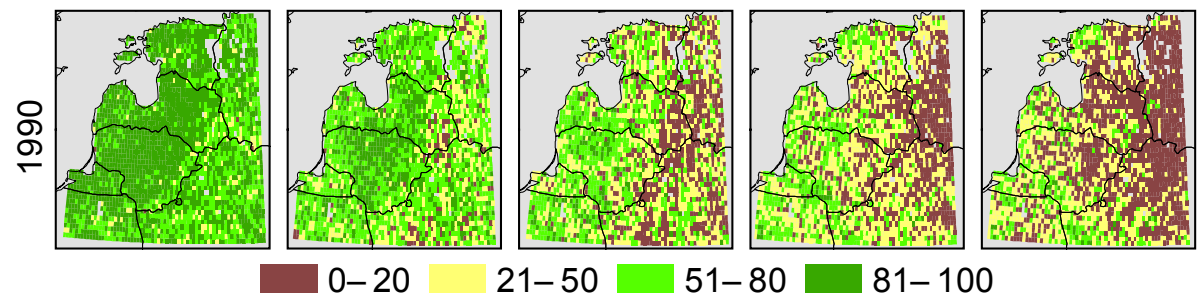

Figure 4. Vegetation condition index (VCI) during the years with cold winter and spring (1987) and warm winter and spring (1990).

a close positive correlation between these dates in all years (Fig. 3).

\subsection{Vegetation condition during the years with different hydrothermal regimes}

NDVI has a strong seasonal pattern. VCI compares the current NDVI to the range of values observed in the same period in previous years (Eq. 2) and is more suitable to illustrating the deviation of vegetation condition from normal (Jain et al., 2010). If the VCI is lower than 50, the vegetation conditions are worse than normal. VCI values in May and June following the cold spring (1987) are smaller than 20 in the majority of the study area (Fig. 4). Within a few months, the vegetation reaches normal conditions again. The warm spring of 1990 led to better vegetation conditions in May and June. In a large part of the area, VCI values were higher than 80. Intensive vegetation in the first part of the year gradually turned into low VCI values in the second half of the vegetation season (Fig. 4).

It seems that the precipitation deficit might not be the decisive factor determining the vegetation condition in the eastern Baltic Sea region. Years 1992 and 2002 had a precipitation amount that was lower than normal during the vegetation season, but in 1992 the vegetation was affected much more than in 2002 (Fig. 5). June 1992 was particularly dry. SPI1, representing the 1-month precipitation deviation from the norm, was lower than -2.0 in a large part of the study area (Fig. 5a). July was dry only in the southeastern part of the analysed region. Both SPI3 and SPI6, which represent the dryness for 3 and 6 months respectively, were the lowest in July and August. The vegetation condition started to decline in some cells in July, but in the majority of the study area the VCI fell below 20 in August and remained similar in September.
The vegetation season of 2002 was also exceptionally dry (Fig. 5b). In July a precipitation deficit was observed in the eastern part of the region, while in August extreme meteorological drought $(\mathrm{SPI} 1 \leq-2.0)$ was determined in almost the entire area except the southeastern part. The precipitation deficit at the beginning of the vegetation season was small, but it gradually accumulated with time and in August and September SPI3 and SPI6 indicated severely or extremely dry conditions in a large part of the study area. However, vegetation was affected only in the southern part of the region (Fig. 5b).

The most important distinction between the dry 1992 and 2002 years was the reaction of vegetation in different land use classes to the precipitation deficit (Fig. 6). In both cases, the vegetation on the arable land was in good condition in May. From June VCI values for the arable land had decreased, and in August-September there were a lot of cells with $\mathrm{VCI}<20$. In land use classes with broadleaved and coniferous vegetation the reaction to the precipitation deficit was different during 1992 and 2002. For example, VCI has decreased more significantly in 1992 than in 2002. Conversely, 1-, 3- and 6-month SPI values calculated for August and September were lower in 2002 than in 1992.

Pearson correlation coefficient between monthly VCI and SPI was calculated to identify the effect of precipitation deficit on the vegetation in a particular cell. The correlation between VCI and the same month SPI1 is usually negative in the study area (Fig. 7a). The negative correlation coefficient shows that higher SPI or wetter conditions lead to lower VCI values. With a longer SPI scale the correlation gradually shifts towards the positive coefficients (Fig. 7a). There is a weak spatial pattern of correlation coefficient distribution. The coefficients in the northern part of the study area tend to be negative, while in the southern part correlation in most cells is positive (Fig. 7a). The correlation is usually positive between the VCI and the previous month's 
(a)

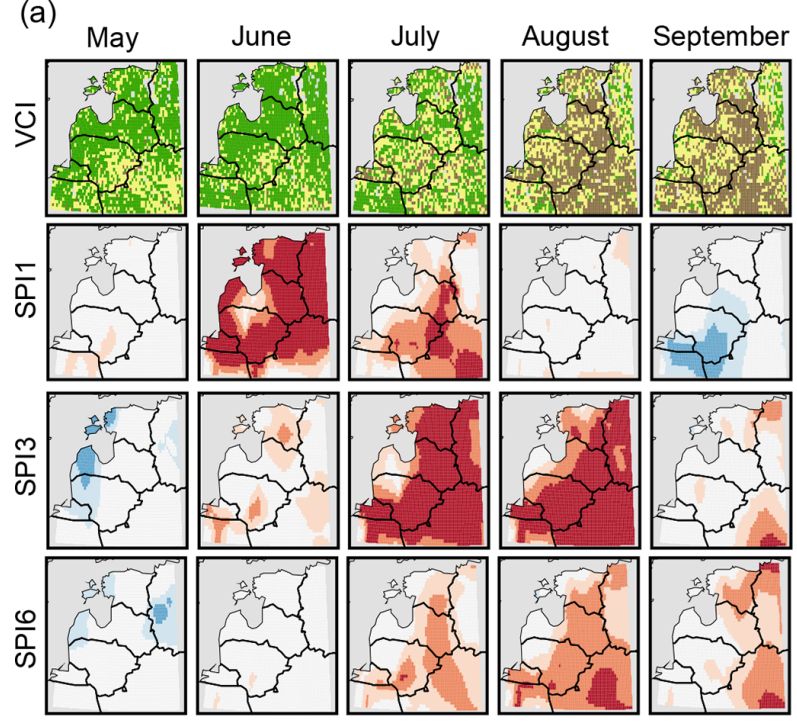

(b)
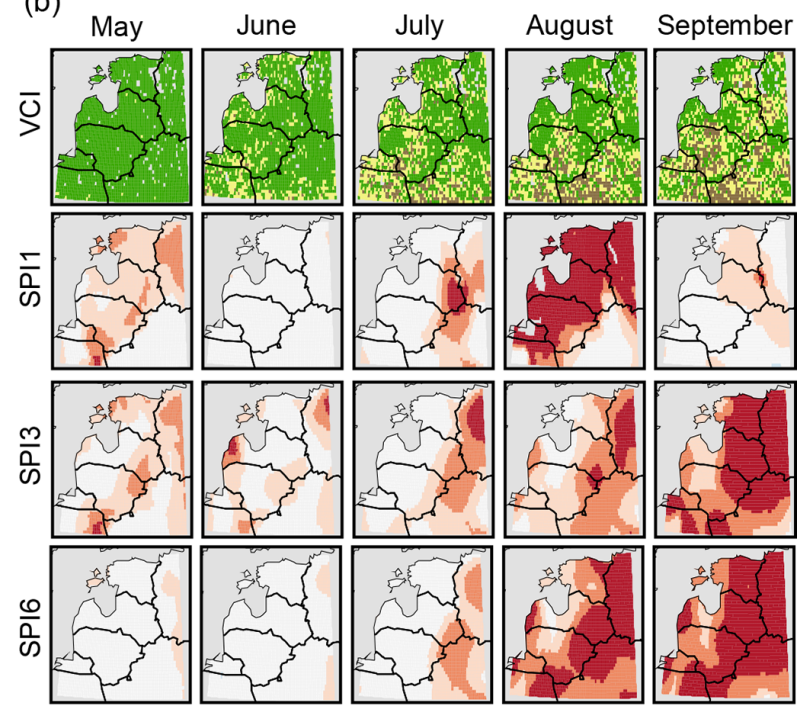

$\mathrm{VCl}$

21-50

SPI

\begin{tabular}{l|l}
$-0.99-0.99 \quad 1.00-1.49$
\end{tabular}

$1.50-1.99$

$\geq 2.00$

Figure 5. Vegetation condition index (VCI) and standardized precipitation index (SPI) during the dry years of 1992 (a) and 2002 (b).

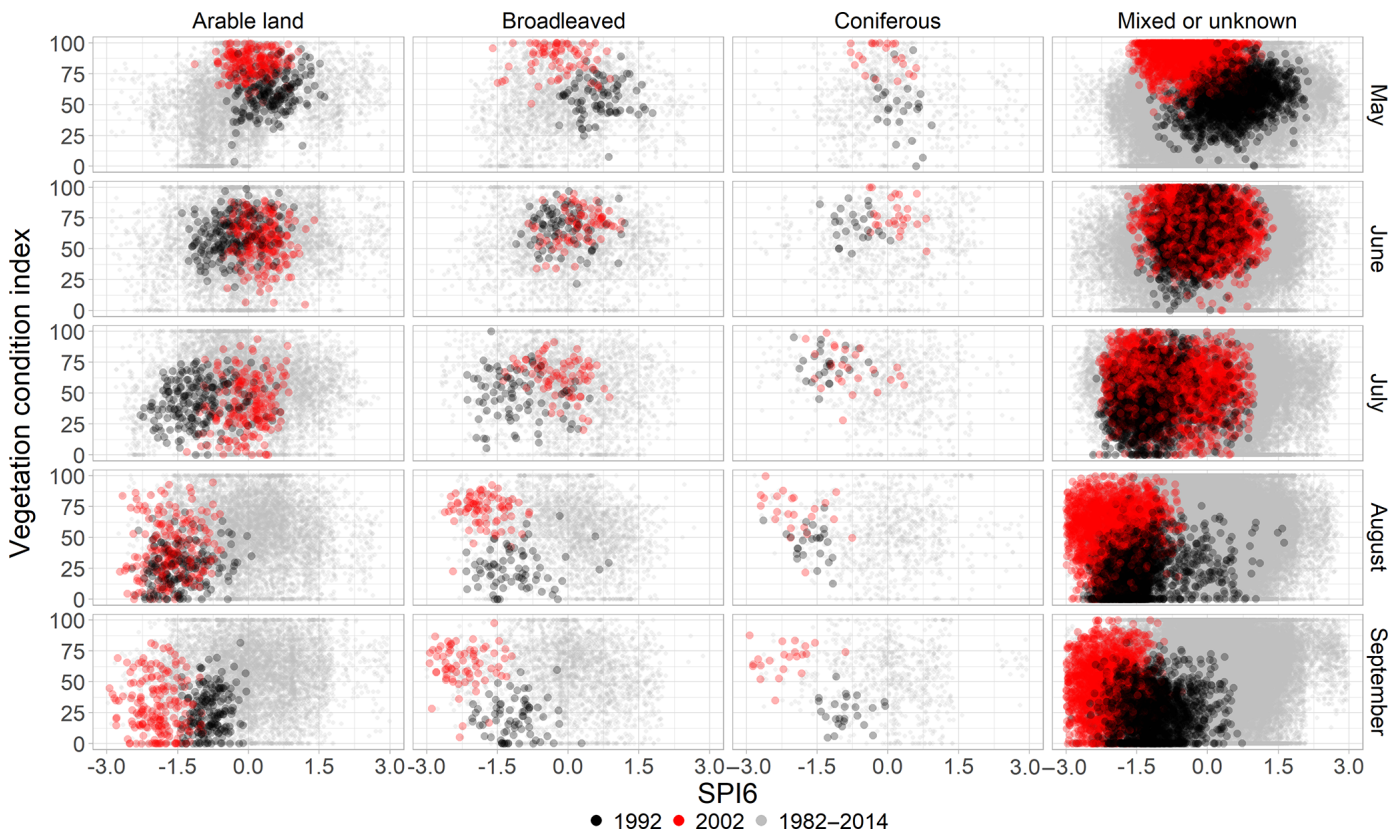

Figure 6. Relationship between SPI6 and VCI for different land use types during the normal (1982-2014) and dry (1992, 2002) years.

SPI (Fig. 7b). There is a cluster of cells with a statistically positive correlation between VCI in May and SPI in April in the western part of the study area. In August and September, a statistically significant positive correlation is common in the southern part of the region. The pattern of correlation between SPI and VCI implies the existence of a spatial factor affecting the relationship. This pattern of VCI and drought indexes has been observed in other studies as well (Quiring and Ganesh, 2010).

When vegetation is affected by a certain factor, its condition may remain distressed for some time. Only the months during which the VCI dropped below 20 for the first time 

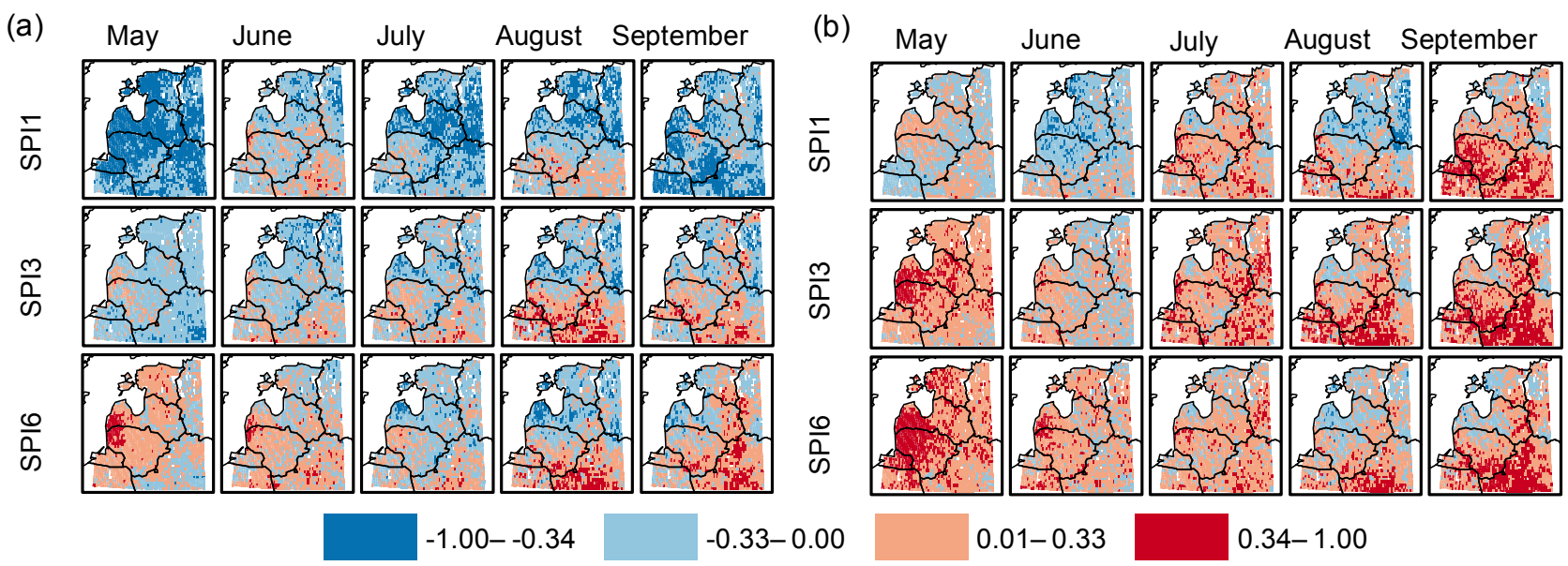

Figure 7. The Pearson correlation coefficient between VCI and SPI values of the same month (a) and between VCI and SPI with 1-month lead (b). Coefficients larger than 0.34 and smaller than -0.34 are statistically significant at $0.95 \%$.

were used to identify how the SPI values are distributed when VCI indicates poor vegetation condition $(\mathrm{VCI}<20)$ (Fig. 8). The distributions of SPI values 1 month before the VCI drops below 20 have weak positive skew. A higher density of SPI values indicating severely or extremely dry conditions (SPI $\leq-1.5)$ could be expected if the decrease in vegetation condition were caused mainly by the significant precipitation deficit. In the majority of months and all land use classes the SPI values indicated normal or moderately dry conditions $(-1.49<\mathrm{SPI}<1.0)$ before VCI dropped below 20. However, according to SPI1 the vegetation condition in June can worsen even after a wet May (Fig. 8).

\section{Discussion}

NDVI values in the analysed area are determined by a number of climatic factors. On average, the active growing season in the Baltic states lasts from the end of April until the beginning of October. The spatial pattern of the seasonal NDVI variation is closely related to the distance from the sea, because the Baltic Sea is a major factor, determining the temperature and precipitation regime in the analysed area (Jaagus et al., 2010, 2014). The differences in NDVI values in spring and autumn in the west-east direction are larger than in the south-north direction. The south-north NDVI gradient would be more noticeable if the determining factors were the length of day and insolation.

Many studies show that beginning of the active growing season is determined by the spring temperature prior to the event (Jeong et al., 2011; Shen et al., 2014) in the temperate and high latitudes of the Northern Hemisphere. In spring the soil is saturated with meltwater and excess moisture can worsen vegetation condition. Agricultural activity on arable land usually starts when soil becomes rather dry. For this reason, in the case of an abnormally wet spring, the negative
NDVI anomalies can be recorded in May, which may be associated with the crop area and not with the crop conditions (Zhang et al., 2014). Conversely, in June moisture deficit in the arable soil may lead to vegetation deterioration, while this effect in conifer and broadleaved forests is almost invisible. Such differences can be explained by the fact that on the arable land mostly annual crops with relatively shallow roots are grown. Thus, a lack of moisture may occur even during the short dry period. The Northern Hemisphere boreal forests usually grow in areas of excessive moisture and tree roots are deeper, so they react much slower to the precipitation deficit (such deficit may even lead to higher VCI values). Also, due to the high initial soil moisture, the drought impact on forested areas can be minimal (Gao et al., 2016). Only during the prolonged extreme droughts (e.g. 1992), do the VCI values in the forests of the study area decrease significantly.

Many studies indicate that VCI reacts with a delay in the change of moisture conditions and this reaction is controlled by the previously accumulated soil water storage (Quiring and Ganesh, 2010). Therefore, the strongest connection between SPI and VCI was determined in the areas with low soil water-holding capacity (Ji and Peters, 2003). Other studies also showed that forests respond to the drought on long-term scales, while arable land does so on short-term scales (Li and Zhou, 2015).

In the second half of the active growing season, the positive correlation between SPI3, SPI6 and VCI has been determined in a large part of the territory. A positive and in many places statistically significant correlation was found in the first half of the season if SPI with a 1-month lead was used. However, the moisture deficit has a significant impact on vegetation condition only in the second half of the active growing season in the analysed part of the Baltic Sea region. Meanwhile, in the drier areas, SPI6 and SPI9 have a strong 


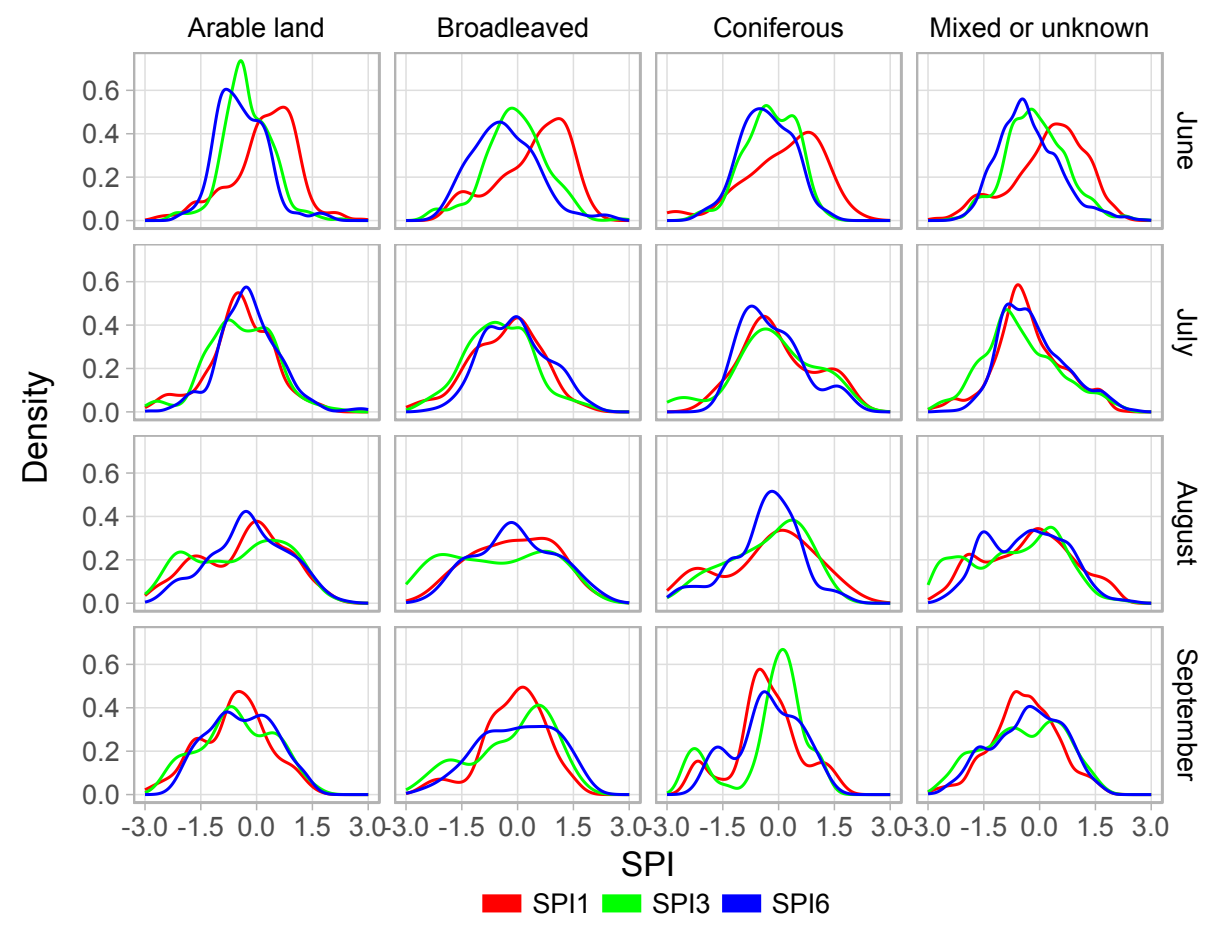

Figure 8. The distribution of SPI values for different land uses 1 month before VCI drops below 20.

positive correlation with VCI throughout the year (Quiring and Ganesh, 2010).

It should be mentioned that due to the early start of the active growing season the peak of vegetation is usually reached earlier, and an early vegetation start does not always lead to an increase in aboveground production (Livensperger et al., 2016). Therefore, the low VCI values in August and September are not always related to the precipitation deficit. However, the time when the NDVI values fall close to the typical winter values (end of October to beginning of November) in arable soils and broadleaved forests is very similar during the years with different hydrothermal regimes (Fig. 3). This is related to the routine agricultural practices on the arable lands (when the land is plowed in autumn) while the fall of tree leaves is associated with the occurrence of the first intense frosts, which are usually in October. Meanwhile, in the coniferous forests, the differences in NDVI values that form in the summer months remain until the end of the calendar year (Fig. 3).

In the arid and semiarid areas, the spatial and temporal patterns of vegetation are primarily related to precipitation (Wang et al., 2001). The analysed region has a surplus precipitation during most of the years; thus, the air temperature anomalies might be the limiting factor for vegetation condition, especially in the transitional seasons (spring and autumn). The comparison of 1987 (cold spring) and 1990 (warm spring) also indicates that the interpretation of VCI values as indicators of drought severity (Kogan, 2002) may not be universal in the eastern part of the Baltic Sea region.
Dabrowska-Zielinska et al. (2002) also found that in nearby Poland the VCI plays a minor role in defining vegetation condition and crop yield.

\section{Conclusions}

The early spring air temperature, snowmelt water storage in the soil and precipitation have the largest influence on NDVI values in the first half of the active growing season. Negative correlation between SPI1 and VCI shows that the short-term precipitation deficit leads to a better vegetation condition. With a longer SPI scale, the correlation coefficients become positive, which shows that longer periods of moisture deficit reduce vegetation condition. The correlation is usually positive between the VCI and the previous month's SPI because vegetation responds to the external forcing with a delay.

The precipitation deficit in the first part of the vegetation season has a significant impact only on the vegetation on arable land, while vegetation in forests is less sensitive to the moisture deficit in the first half of the active growing season. The positive correlation between 3- and 6-month SPI and VCI was observed on the arable land and both types of forests in the second half of the vegetation season.

The precipitation deficit is only one of the vegetation condition drivers in the eastern Baltic region and NDVI or VCI cannot be universally used to identify droughts. However, NDVI and VCI may be applied to better assess the effect of droughts on vegetation and the crop damage. 
Data availability. NDVI data were obtained from the NOAA STAR-NESDIS system ftp://ftp.star.nesdis.noaa.gov/pub/corp/ scsb/wguo/data/VHP_16km/VH/.

Precipitation data were obtained from the CRU TS database https://doi.org/10.5285/D0E1585D-3417-485F-87AE4FCECF10A992.

CORINE land cover data were obtained from the EEA database http://land.copernicus.eu/pan-european/corine-land-cover.

Competing interests. The authors declare that they have no conflict of interest.

Special issue statement. This article is part of the special issue "Multiple drivers for Earth system changes in the Baltic Sea region". It is a result of the 1st Baltic Earth Conference, Nida, Lithuania, 13-17 June 2016.

Edited by: Anna Rutgersson

Reviewed by: two anonymous referees

\section{References}

BACC: Assessment of climate change for Baltic Sea region (regional climate studies), edited by: Bolle, H.-J., Menenti, M., and Rasool, I., Springer-Verlag, Berlin, Heidelberg, 2008.

Belal, A. A., El-Ramady, H. R., Mohamed, E. S., and Saleh, A. M.: Drought risk assessment using remote sensing and GIS techniques, Arab. J. Geosci., 7, 35-53, https://doi.org/10.1007/s12517-012-0707-2, 2014.

Bhuiyan, C., Singh, R. P., and Kogan, F. N.: Monitoring drought dynamics in the Aravalli region (India) using different indices based on ground and remote sensing data, Int. J. Appl. Earth Obs., 8, 289-302, https://doi.org/10.1016/j.jag.2006.03.002, 2006.

Bijak, S.: Influence of drought on radial growth of Norway spruce in north-eastern Poland, in: Proceedings of the DENDROSYMPOSIUM 2010: April 22nd-25th, 2010 in Freiburg, Germany, (Scientific Technical Report; 11/07), 9th TRACE (Tree Rings in Archaeology, Climatology and Ecology) conference (Freiburg 2010), Potsdam: Deutsches GeoForschungsZentrum GFZ, edited by: van der Maaten-Theunissen, M., Spiecker, H., Gärtner, H., Heinrich, I., and Helle, G., 9, 28-33, https://doi.org/10.2312/GFZ.b103-11074, 2011.

Bordi, I., Fraedrich, K., and Sutera, A.: Observed drought and wetness trends in Europe: an update, Hydrol. Earth Syst. Sci., 13, 1519-1530, https://doi.org/10.5194/hess-13-1519-2009, 2009.

Dabrowska-Zielinska, K., Kogan, F. N., Ciolkosz, A., Gruszczynska, M., and Kowalik, W.: Modelling of crop growth conditions and crop yield in Poland using AVHRRbased indices, Int. J. Remote Sens., 23, 1109-1123, https://doi.org/10.1080/01431160110070744, 2002.

Dutta, D., Kundu, A., Patel, N. R., Saha, S. K., and Siddiqui, A. R.: Assessment of agricultural drought in Rajasthan (India) using remote sensing derived Vegetation Condition Index (VCI) and Standardized Precipitation Index (SPI), The Egyptian Journal of Remote Sensing and Space Sciences, 18, 53-63, https://doi.org/10.1016/j.ejrs.2015.03.006, 2015.
Edwards, D. C. and McKee, T. B.: Characteristics of 20th century drought in the United States at multiple time scales, Atmospheric Science Paper No. 634, Colorado State University, Fort Collins, USA, 1997.

Gaikwad, Y. and Bhosale, R.: Survey on predictive analysis of drought in India using AVHRR-NOAA remote sensing data, Int. J. Adv. Found. Res. Comput., 1, ISSN 2348-4853, 2014.

Gao, Y., Markkanen, T., Thum, T., Aurela, M., Lohila, A., Mammarella, I., Kämäräinen, M., Hagemann, S., and Aalto, T.: Assessing various drought indicators in representing summer drought in boreal forests in Finland, Hydrol. Earth Syst. Sci., 20, 175-191, https://doi.org/10.5194/hess-20-175-2016, 2016.

Gebrehiwot, T., van der Veen, A., and Maathuis, B.: Spatial and temporal assessment of drought in the Northern highlands of Ethiopia. Int. J. Appl. Earth Obs., 13, 309-321, https://doi.org/10.1016/j.jag.2010.12.002, 2011.

Harris, I., Jones, P. D., Osborn, T. J., and Lister, D. H.: Updated high-resolution grids of monthly climatic observations - the CRU TS3.10 Dataset, Int. J. Climatol, 34, 623-642, https://doi.org/10.1002/joc.3711, 2013.

Holben, B. N.: Characteristics of maximum-value composite images from temporal AVHRR data, Int. J. Remote. Sens., 7, 14171434, https://doi.org/10.1080/01431168608948945, 1986.

Jaagus, J., Briede, A., Rimkus, E., and Remm, K.: Precipitation pattern in the Baltic countries under the influence of large-scale atmospheric circulation and local landscape factors, Int. J. Climatol., 30, 705-720, https://doi.org/10.1002/joc.1929, 2010.

Jaagus, J., Briede, A., Rimkus, E., and Remm, K.: Variability and trends in daily minimum and maximum temperatures and in the diurnal temperature range in Lithuania, Latvia and Estonia in 1951-2010, Theor. Appl. Climatol., 118, 57-68, https://doi.org/10.1007/s00704-013-1041-7, 2014.

Jackson, R. D. and Huete, A. R.: Interpreting vegetation indices, Prev. Vet. Med., 11, 185-200, https://doi.org/10.1016/S01675877(05)80004-2, 1991.

Jain, S. K., Keshri, R., Goswami, A., and Sarkar, A.: Application of meteorological and vegetation indices for evaluation of drought impact: a case study for Rajasthan, India, Nat. Hazards, 54, 643656, https://doi.org/10.1007/s11069-009-9493-x, 2010.

Jeong, S.-J., Ho, C.-H., Gim, H.-J., and Brown, M. E.: Phenology shifts at start vs. end of growing season in temperate vegetation over the Northern Hemisphere for the period 1982-2008, Glob. Change Biol., 17, 2385-2399, https://doi.org/10.1111/j.13652486.2011.02397.x, 2011.

Ji, L. and Peters, A. J.: Assessing vegetation response to drought in the northern Great Plains using vegetation and drought indices, Remote Sens. Environ., 87, 85-98, https://doi.org/10.1016/S0034-4257(03)00174-3, 2003.

Kalbarczyk, R.: Temporal and spatial diversity of the occurrence of atmospheric drought in Poland (1966-2005) and its effect of yield of pickling cucumber (Cucumis sativus L.), Span. J. Agric. Res., 8, 1147-1162, https://doi.org/10.5424/sjar/2010084-1405, 2010.

Kogan, F. N.: Application of vegetation index and brightness temperature for drought detection, Adv. Space. Res., 15, 91-100, https://doi.org/10.1016/0273-1177(95)00079-T, 1995.

Kogan, F. N.: Global drought watch from space, B. Am. Meteorol. Soc., 78, 621-636, 1997. 
Kogan, F. N.: World droughts in the new millennium from AVHRRbased Vegetation Health Indices, Eos T. Am. Geophys. Un., 83, 557-563, https://doi.org/10.1029/2002EO000382, 2002.

Kulikauskas, A. and Sprainaitiene, J.: Productivity of oats varieties and lines in relation to the air temperature and precipitation distribution within the growing season, Agric. Sci. Articles, 89, 93102, 2005 (in Lithuanian).

Li, Z. and Zhou, T.: Responses of vegetation growth to climate change in china, Int. Arch. Photogramm. Remote Sens. Spatial Inf. Sci., XL-7/W3, 225-229, https://doi.org/10.5194/isprsarchives-XL-7-W3-225-2015, 2015.

Lillesand, T. M. and Kiefer, R. W.: Remote Sensing and Image Interpretation, 3rd Edn., Wiley \& Sons, New York, 1994.

Livensperger, C., Steltzer, H., Darrouzet-Nardi, A., Sullivan, P. F., Wallenstein, M., and Weintraub, M. N.: Earlier snowmelt and warming lead to earlier but not necessarily more plant growth, AoB PLANTS, 8, plw021, https://doi.org/10.1093/aobpla/plw021, 2016.

Loyd-Hughes, B. and Saunders, M. A.: A drought climatology for Europe, Int. J. Climatol., 22, 1571-1592, https://doi.org/10.1002/joc.846, 2002.

McKee, T. B., Doesken, N. J., and Kleist, J.: The relationship of drought frequency and duration to time scales, in: Proceedings of the 8th Conference on Applied Climatology, Am. Meteor. Soc., 17-22 January, Anaheim, USA, 179-184, 1993.

Mirzaei, F. T., Tajamolian, M., Sarkargar A. A., and Azimzadeh, H.: Study of the vegetation effect on dust reduction using satellite images (case study: Yazd city), International Geoinformatics Research and Development Journal, 2, 11-16, 2011.

Myneni, R. B., Hall, F. G., Sellers, P. J., and Marshak A. L.: The interpretation of spectral vegetation indexes, IEEE T. Geosci. Remote, 33, 481-486, 1995.

NOAA-NESDIS: AVHRR Vegetation Health Product (AVHRRVHP) User Guide, available at: http://star.nesdis.noaa.gov/ (last access: 5 January 2017, 2013.

Ozelkan, E., Chen, G., and Ustundag, B. B.: Multiscale objectbased drought monitoring and comparison in rainfed and irrigated agriculture from Landsat 8 OLI imagery, Int. J. Appl. Earth Obs., 44, 159-170, https://doi.org/10.1016/j.jag.2015.08.003, 2016.

Ozolincius, R., Stakenas, V., Varnagiryte-Kabasinskiene, I., and Buozyte, R.: Artificial drought in Scots pine stands: effects on soil, ground vegetation and tree condition, Ann. Bot. Fenn., 46, 299-307, 2009.

Quiring, S. M. and Ganesh, S.: Evaluating the utility of the Vegetation Condition Index (VCI) for monitoring meteorological drought in Texas, Agr. Forest Meteorol., 150, 330-339, https://doi.org/10.1016/j.agrformet.2009.11.015, 2010.
Rimkus, E., Valiukas, D., Kazys, J., Gecaite, I., and Stonevicius, E.: Dryness dynamics of the Baltic Sea region, Baltica, 25, 129-142, https://doi.org/10.5200/baltica.2012.25.13, 2012.

Rimkus, E., Stonevicius, E., Korneev, V., Kazys, J., Valiuskevicius, G., and Pakhomau, A.: Dynamics of meteorological and hydrological droughts in the Neman river basin, Environ. Res. Lett., 8, 045014, https://doi.org/10.1088/1748-9326/8/4/045014, 2013.

Rimkus, E., Kazys, J., Valiukas, D., and Stankunavicius, G.: The atmospheric circulation patterns during dry periods in Lithuania, Oceanologia, 56, 223-239, https://doi.org/10.5697/oc.56-2.223, 2014.

Scheftic, W., Zeng, X., Broxton, P., and Brunke, M.: Intercomparison of seven NDVI products over the United States and Mexico, Remote Sens., 6, 1057-1084, https://doi.org/10.3390/rs6021057, 2014.

Shen, M., Tang, Y., Chen, J., Yang, X., Wang, C., Cui, X., Yang, Y., Han, L., Li, L., Du, J., Zhang, G., and Cong, N.: Earlierseason vegetation has greater temperature sensitivity of spring phenology in Northern hemisphere, PLoS ONE 9, e88178, https://doi.org/10.1371/journal.pone.0088178, 2014.

Stagge, J. H., Kohn, I., Tallaksen, L. M., and Stahl, K.: Modeling drought impact occurrence based on meteorological drought indices in Europe, J. Hydrol., 530, 37-50, https://doi.org/10.1016/j.jhydrol.2015.09.039, 2015.

Stonevicius, E., Rimkus, E., Staras, A., Kazys, J., and Valiuskevicius, G.: Climate change impact on the Nemunas River basin hydrology in the 21st century, Boreal Environ. Res., 22, 49-65, 2017.

Usman, U., Yelwa, S. A., Gulumbe, S. U., and Danbaba A.: Modelling Relationship between NDVI and Climatic Variables Using Geographically Weighted Regression, Journal of Mathematical Sciences and Applications, 1, 24-28, 2013.

Valiukas, D.: Analysis of droughts and dry periods in Lithuania, Summary of Doctoral Dissertation, Vilnius university, Vilnius, Lithuania, 1-49, 2015.

Vitas, A. and Erlickyte, R.: Influence of droughts to the radial growth of Scots pine (Pinus sylvestris L.), Ekológia (Bratislava), 27, 367-378, 2008.

Wang, J., Price, K. P., and Rich, P. M.: Spatial patterns of NDVI in response to precipitation and temperature in the central Great Plains, Int. J. Remote Sens., 22, 3827-3844, https://doi.org/10.1080/01431160010007033, 2001.

Zhang, M., Wu, B., Yu, M., Zou, W., and Zheng, Y.: Crop condition assessment with adjusted NDVI using the uncropped arable land ratio, Remote Sens., 6, 5774-5794, https://doi.org/10.3390/rs6065774, 2014. 